\section{International Scientific Journal Theoretical \& Applied Science}

p-ISSN: 2308-4944 (print)

e-ISSN: 2409-0085 (online)

Year: 2016

Issue: 4

Volume: 36

Published: $30.04 .2016 \quad$ http://T-Science.org
Gary B. Lapiz

B.P.A., M.P.A., D.P.A.

Resident Faculty, Department of Public Governance

College of Arts and Sciences

Cebu Normal University, Cebu City, Philippines instructor_lapiz@yahoo.com.ph

SECTION 19. Management. Marketing. Public Administration.

\title{
EXCERPT THEORIES ABOUT POWER: AN EXPOSITION
}

Abstract: Power as the focal point of this research is an exposition of some excerpt theories on normative standards vis-à-vis the actual use of power in all fields of practice in governance and other related endeavors. All throughout, politics and administration is inseparable, such is its universal prevalence among leaders in the varied positions of conceptualization and application. As per the conduct of the study, using the qualitative approach, the researcher biased through content analysis the selection of theories towards value judgement vis-a-vis choice on normative-prescription where the theories were processed towards its sound and valid results and conclusion. The exposition of excerpt theories showed diverse power stratagem on rational choice upon use. The speculation upon application depends upon perception through discernment on processing based on mindset and application to the scenario upon which it is anchored upon theories towards political reality. Thus, leaders are entangled ways and means on how they are to achieve their end(s) through the use of power and among those who aspire towards the end of leadership per se.

Key words: Theories and Practice, Power, Governance.

Language: English

Citation: Lapiz GB (2016) EXCERPT THEORIES ABOUT POWER: AN EXPOSITION. ISJ Theoretical \& Applied Science, 04 (36): 1-12.

Soi: http://s-o-i.org/1.1/TAS-04-36-1 Doi: crossef http://dx.doi.org/10.15863/TAS.2016.04.36.1

\section{INTRODUCTION}

Hanore de Balzac in his line as Erick Kristian quoted on twitter.com that says, "When you doubt your power, you give power to your doubt" is the usual dilemma any leader experiences when one is in power or else whenever one wants power. One may have the power but does not have the acumen skill of utilizing it. The aforementioned is an assumption that such a political leader commits "mortal sin" behind the value and logic of power, ignorance and an insult to one's political capacity that is to power itself in order to move heaven and earth according to one's intention whether good or bad but is aimed at preserving one's interest, better, if it is for the good and not for the worst end in the exercise of authority. This, Eric Hoffer (1902-1983), an American writer quotes, "The only way to predict the future is to have power to shape the future."

Politics and administration is inseparable, such is its universal prevalence among leaders in the varied positions of conceptualization and application. All throughout public administration, leaders rise and fall and one of the fundamental question is, "How can one acquire, stay and prolong power in authority despite administrative and legitimate limitations?

Consequently, "What are some of the mechanisms for one to sustain power in authority?" Along the aforementioned rational realities, thus, this research comes to the writer's mind.

\section{OBJECTIVE OF THE STUDY}

This paper aims to present some selected theories on power as alternative prescription(s) to those leaders in authority vis-à-vis its acquisition, retention and or sustenance.

\section{METHODOLOGY}

As per the conduct of the study, using the qualitative approach, the researcher biased through content analysis the selection of theories towards value judgement vis-a-vis choice on normativeprescription where the theories were processed towards its sound and valid results and conclusion. 


\begin{tabular}{|c|c|c|c|c|c|c|}
\hline Impact Factor: & $\begin{array}{l}\text { ISRA (India) } \\
\text { ISI (Dubai, UAF } \\
\text { GIF (Australia) } \\
\text { JIF }\end{array}$ & $\begin{array}{l}=1.344 \\
=0.829 \\
=0.564 \\
=1.500\end{array}$ & $\begin{array}{l}\text { SIS (USA) } \\
\text { PИНЦ (Russia) } \\
\text { ESJI (KZ) } \\
\text { SJIF (Morocco) }\end{array}$ & $\begin{array}{l}=0.912 \\
=0.179 \\
=1.042 \\
=2.031\end{array}$ & $\begin{array}{l}\text { ICV (Poland) } \\
\text { PIF (India) } \\
\text { IBI (India) }\end{array}$ & $\begin{array}{l}=6.630 \\
=1.940 \\
=4.260\end{array}$ \\
\hline
\end{tabular}

\section{EXCERPT THEORIES ABOUT POWER: THE REVIEW OF RELATED STUDIES AND LITERATURE}

\section{A. REVIEW OF LITERATURE}

One of Aristotle's political thought that is still valid today is his idea that says, "Man by nature is a political animal (Zulueta, 2003)." This is where man is conceived to practice power in its relations with others using reason as the prime mover of one's intentions.

Power is a measure of an entity's ability to control the environment around itself, including the behavior of other entities. The term authority is often used for power, perceived as legitimate by the social structure. Power can be seen as evil or unjust, but the exercise of power is accepted as endemic to humans as social beings. In the corporate environment, power is often expressed as upward or downward. With downward power, a company's superior influences subordinate. Power can be also defined as upward in a company. When a company exerts upward power, it is the subordinates who influence the decisions of the leader (Greiner \& Schein, 1988). Often, the study of power in a society is referred to as politics (http://en.wikipedia.org/wiki/Power_\%28philosophy \%29).

McClelland has described "two faces of power" - a negative face and positive one. The negative face is usually expressed in terms of dominance-submission: If I win, you lose. In this sense, to have power implies having power over someone else, who is less well off for it (Stoner, Freeman and Gilbert, 1999).

The use of power need not involve coercion (force or the threat of force). At one extreme, it more closely resembles what everydayEnglish-speakers call "influence", although some authors make a distinction between power and influence - the means by which power is used (Handy, C. 1993 Understanding Organisations) (http://en.wikipedia.org/wiki/Power_\%28philosophy $\% 29)$.

Much of the recent sociological debate on power revolves around the issue of the enabling nature of power. A comprehensive account of power can be found in Steven LukesPower: A Radical View where he discusses the three dimensions of power. Thus, power can be seen as various forms of constraint on human action, but also as that which makes action possible, although in a limited scope. Much of this debate is related to the works of the French philosopher Michel Foucault (1926-1984), who, following the Italian political philosopher Niccolò Machiavelli (1469-1527), sees power as "a complex strategic situation in a given society social setting". Being deeply structural, his concept involves both constraint and enablement. For a purely enabling (and voluntaristic) concept of power see the works of Anthony Giddens (http://en.wikipedia.org/wiki/Power_\%28philosophy $\% 29)$.

Power may be held through (http://en.wikipedia.org/wiki/Power_\%28philosophy $\% 29)$ :

- Delegated authority (for example in the democratic process)

- Social class (material wealth can equal power)

- Personal or group charisma

- Ascribed power (acting on perceived or assumed abilities, whether these bear testing or not)

- Expertise (ability, skills) (the power of medicine to bring about health; another famous example would be "in the land of the blind, the oneeyed man is king" - Desiderius Erasmus)

- Persuasion (direct, indirect, or subliminal)

- Knowledge (granted or withheld, shared or kept secret

- Celebrity

- Force (violence, military might, coercion).

- Moral persuasion (including religion)

- Operation of group dynamics (such as public relations)

- Social influence of tradition (compare ascribed power)

- In relationships; domination/submissiveness

John R. P. French and Bertran Raven in "The Bases of Power" as mentioned by Dannug and Campanilla (2004) suggest that there are five major bases of power which can also be aptly described as the Star of Power.

1. Expert power is based on the perception that the leader possesses some special knowledge or expertise.

2. Referent power is based on the follower's liking, admiring, or identifying with the leader.

3. Reward power is based on the leader's capacity to mediate rewards for the follower.

4. Legitimate power is based on the follower's perception that the leader has the legitimate right or authority to exercise influence over him or her.

5. Coercive power is based on the follower's fear that non-compliance with the leader's wishes will lead to punishment.

Subsequent research on these power bases indicates that the first two (expert and referent power) are more positively related to subordinate performance and satisfaction than the last three 
(reward, legitimate and coercive power) (Dannug and Campanilla, 2004).

Whatever the source of power is, it is important that a leader has to use his or her power wisely. As such, Robert Green's work has popularized in which important political commandments are enumerated in order to optimize the full value and logic of power.

Val Dorado as posted on http://ezinearticles.com/?Book-Review-on-the-48Laws-of-Power-by-Robert-Greene\&id=2053090 mentions the highlights of Robert Green's work pertaining to his laws of power as:

\section{Never Outshine the Master}

Always make those above you feel comfortably superior. In your desire to please or impress them, do not go too far in displaying your talents or you might accomplish the opposite - inspire fear and insecurity. Make your masters appear more brilliant than they are and you will attain the heights of power.

\section{Never put too Much Trust in Friends, Learn how to use Enemies}

Be wary of friends-they will betray you more quickly, for they are easily aroused to envy. They also become spoiled and tyrannical. But hire a former enemy and he will be more loyal than a friend, because he has more to prove. In fact, you have more to fear from friends than from enemies. If you have no enemies, find a way to make them.

\section{Conceal your Intentions}

Keep people off-balance and in the dark by never revealing the purpose behind your actions. If they have no clue what you are up to, they cannot prepare a defense. Guide them far enough down the wrong path, envelope them in enough smoke, and by the time they realize your intentions, it will be too late.

\section{Always Say Less than Necessary}

When you are trying to impress people with words, the more you say, the more common you appear, and the less in control. Even if you are saying something banal, it will seem original if you make it vague, open-ended, and sphinx like. Powerful people impress and intimidate by saying less. The more you say, the more likely you are to say something foolish.

So Much Depends on Reputation - Guard it with your Life
Reputation is the cornerstone of power. Through reputation alone you can intimidate and win; once you slip, however, you are vulnerable, and will be attacked on all sides. Make your reputation unassailable. Always be alert to potential attacks and thwart them before they happen. Meanwhile, learn to destroy your enemies by opening holes in their own reputations. Then stand aside and let public opinion hang them.

\section{Court Attention at all Cost}

Everything is judged by its appearance; what are unseen counts for nothing. Never let yourself get lost in the crowd, then, or buried in oblivion. Stand out. Be conspicuous, at all cost. Make yourself a magnet of attention by appearing larger, more colorful, and more mysterious, than the bland and timid masses.

Get others to do the Work for you, but always take the Credit

Use the wisdom, knowledge, and legwork of other people to further your own cause. Not only will such assistance save you valuable time and energy, it will give you a godlike aura of efficiency and speed. In the end your helpers will be forgotten and you will be remembered. Never do yourself what others can do for you.

Make other People come to you - use Bait if Necessary

When you force the other person to act, you are the one in control. It is always better to make your opponent come to you, abandoning his own plans in the process. Lure him with fabulous gains - then attack. You hold the cards.

\section{Win through your Actions, Never through Argument}

Any momentary triumph you think gained through argument is really a Pyrrhic victory: The resentment and ill will you stir up is stronger and lasts longer than any momentary change of opinion. It is much more powerful to get others to agree with you through your actions, without saying a word. Demonstrate, do not explicate.

\section{Infection: Avoid the Unhappy and Unlucky}

You can die from someone else's misery emotional states are as infectious as disease. You may feel you are helping the drowning man but you are only precipitating your own disaster. The 
unfortunate sometimes draw misfortune on himself or herself; they will also draw it on you. Associate with the happy and fortunate instead.

\section{Learn to Keep People Dependent on You}

To maintain your independence you must always be needed and wanted. The more you are relied on, the more freedom you have. Make people depend on you for their happiness and prosperity and you have nothing to fear. Never teach them enough so that they can do without you.

\section{Use Selective Honesty and Generosity to Disarm your Victim}

One sincere and honest move will cover over dozens of dishonest ones. Openhearted gestures of honesty and generosity bring down the guard of even the most suspicious people. Once your selective honesty opens a hole in their armor, you can deceive and manipulate them at will. A timely gift - a Trojan horse - will serve the same purpose.

\section{When Asking for Help, Appeal to People's Self-Interest, Never to their Mercy or Gratitude}

If you need to turn to an ally for help, do not bother to remind him of your past assistance and good deeds. He will find a way to ignore you. Instead, uncover something in your request, or in your alliance with him, that will benefit him, and emphasize it out of all proportion. He will respond enthusiastically when he sees something to be gained for himself.

\section{Pose as a Friend, Work as a Spy}

Knowing about your rival is critical. Use spies to gather valuable information that will keep you a step ahead. Better still: Play the spy yourself. In polite social encounters, learn to probe. Ask indirect questions to get people to reveal their weaknesses and intentions. There is no occasion that is not an opportunity for artful spying.

\section{Crush your Enemy Totally}

All great leaders since Moses have known that a feared enemy must be crushed completely. (Sometimes they have learned this the hard way.) If one ember is left alight, no matter how dimly it smolders, a fire will eventually break out. More is lost through stopping halfway than through total annihilation: The enemy will recover, and will seek revenge. Crush him, not only in body but also in spirit.

\section{Use Absence to Increase Respect and Honor}

Too much circulation makes the price go down: The more you are seen and heard from, the more common you appear. If you are already established in a group, temporary withdrawal from it will make you more talked about, even more admired. You must learn when to leave. Create value through scarcity.

\section{Keep Others in Suspended Terror: Cultivate an Air of Unpredictability}

Humans are creatures of habit with an insatiable need to see familiarity in other people's actions. Your predictability gives them a sense of control. Turn the tables: Be deliberately unpredictable. Behavior that seems to have no consistency or purpose will keep them off-balance, and they will wear themselves out trying to explain your moves. Taken to an extreme, this strategy can intimidate and terrorize.

\section{Do Not Build Fortresses to protect yourself - Isolation is Dangerous}

The world is dangerous and enemies are everywhere - everyone has to protect themselves. A fortress seems the safest. But isolation exposes you to more dangers than it protects you from - it cuts you off from valuable information, it makes you conspicuous and an easy target. Better to circulate among people find allies, mingle. You are shielded from your enemies by the crowd.

\section{Know who you're Dealing with - Do Not Offend the Wrong Person}

There are many different kinds of people in the world, and you can never assume that everyone will react to your strategies in the same way. Deceive or outmaneuver some people and they will spend the rest of their lives seeking revenge. They are wolves in lambs' clothing. Choose your victims and opponents carefully, then - never offend or deceive the wrong person.

\section{Do Not Commit to Anyone}

It is the fool who always rushes to take sides. Do not commit to any side or cause but yourself. By maintaining your independence, you become the master of others - playing people against one another, making them pursue you.

Play a Sucker to Catch a Sucker - Seem Dumber than your Mark 
No one likes feeling stupider than the next persons. The trick is to make your victims feel smart - and not just smart, but smarter than you are. Once convinced of this, they will never suspect that you may have ulterior motives.

\section{Use the Surrender Tactic: Transform Weakness into Power}

When you are weaker, never fight for honor's sake; choose surrender instead. Surrender gives you time to recover, time to torment and irritate your conqueror, time to wait for his power to wane. Do not give him the satisfaction of fighting and defeating you - surrender first. By turning the other check you infuriate and unsettle him. Make surrender a tool of power.

\section{Concentrate Your Forces}

Conserve your forces and energies by keeping them concentrated at their strongest point. You gain more by finding a rich mine and mining it deeper, than by flitting from one shallow mine to another intensity defeats extensity every time. When looking for sources of power to elevate you, find the one key patron, the fat cow who will give you milk for a long time to come.

\section{Play the Perfect Courtier}

The perfect courtier thrives in a world where everything revolves around power and political dexterity. He has mastered the art of indirection; he flatters, yields to superiors, and asserts power over others in the mot oblique and graceful manner. Learn and apply the laws of courtiership and there will be no limit to how far you can rise in the court.

\section{Re-Create Yourself}

Do not accept the roles that society foists on you. Re-create yourself by forging a new identity, one that commands attention and never bores the audience. Be the master of your own image rather than letting others define if for you. Incorporate dramatic devices into your public gestures and actions - your power will be enhanced and your character will seem larger than life.

\section{Keep Your Hands Clean}

You must seem a paragon of civility and efficiency: Your hands are never soiled by mistakes and nasty deeds. Maintain such a spotless appearance by using others as scapegoats and cat's-paws to disguise your involvement.
Play on People's Need to Believe to Create a Cultlike Following

People have an overwhelming desire to believe in something. Become the focal point of such desire by offering them a cause, a new faith to follow. Keep your words vague but full of promise; emphasize enthusiasm over rationality and clear thinking. Give your new disciples rituals to perform, ask them to make sacrifices on your behalf. In the absence of organized religion and grand causes, your new belief system will bring you untold power.

\section{Enter Action with Boldness}

If you are unsure of a course of action, do not attempt it. Your doubts and hesitations will infect your execution. Timidity is dangerous: Better to enter with boldness. Any mistakes you commit through audacity are easily corrected with more audacity. Everyone admires the bold; no one honors the timid.

\section{Plan All the Way to the End}

The ending is everything. Plan all the way to it, taking into account all the possible consequences, obstacles, and twists of fortune that might reverse your hard work and give the glory to others. By planning to the end you will not be overwhelmed by circumstances and you will know when to stop. Gently guide fortune and help determine the future by thinking far ahead.

\section{Make Your Accomplishments Seem Effortless}

Your actions must seem natural and executed with ease. All the toil and practice that go into them, and also all the clever tricks, must be concealed. When you act, act effortlessly, as if you could do much more. Avoid the temptation of revealing how hard you work - it only raises questions. Teach no one your tricks or they will be used against you.

\section{Control the Options: Get others to play with the Cards You Deal}

The best deceptions are the ones that seem to give the other person a choice: Your victims feel they are in control, but are actually your puppets. Give people options that come out in your favor whichever one they choose. Force them to make choices between the lesser of two evils, both of which serve your purpose. Put them on the horns of a dilemma: They are gored wherever they turn. 


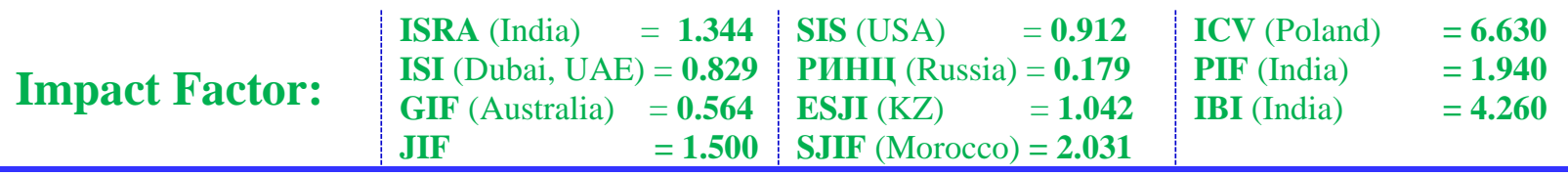

\section{Play to People's Fantasies}

The truth is often avoided because it is ugly and unpleasant. Never appeal to truth and reality unless you are prepared for the anger that comes for disenchantment. Life is so harsh and distressing that people who can manufacture romance or conjure up fantasy are like oases in the desert: Everyone flocks to them. There is great power in tapping into the fantasies of the masses.

\section{Discover Each Man's Thumbscrew}

Everyone has a weakness, a gap in the castle wall. That weakness is usual $\mathrm{y}$ insecurity, an uncontrollable emotion or need; it can also be a small secret pleasure. Either way, once found, it is a thumbscrew you can turn to your advantage.

\section{Be Royal in your Own Fashion: Act like a King to be treated like one}

The way you carry yourself will often determine how you are treated; In the long run, appearing vulgar or common will make people disrespect you. For a king respects himself and inspires the same sentiment in others. By acting regally and confident of your powers, you make yourself seem destined to wear a crown.

\section{Master the Art of Timing}

Never seem to be in a hurry - hurrying betrays a lack of control over yourself, and over time. Always seem patient, as if you know that everything will come to you eventually. Become a detective of the right moment; sniff out the spirit of the times, the trends that will carry you to power. Learn to stand back when the time is not yet ripe, and to strike fiercely when it has reached fruition.

\section{Disdain Things You cannot have: Ignoring them is the best Revenge}

By acknowledging a petty problem you give it existence and credibility. The more attention you pay an enemy, the stronger you make him; and a small mistake is often made worse and more visible when you try to fix it. It is sometimes best to leave things alone. If there is something you want but cannot have, show contempt for it. The less interest you reveal, the more superior you seem.

\section{Create Compelling Spectacles}

Striking imagery and grand symbolic gestures create the aura of power - everyone responds to them. Stage spectacles for those around you, then full of arresting visuals and radiant symbol that heighten your presence. Dazzled by appearances, no one will notice what you are really doing.

\section{Think as you like but Behave like others}

If you make a show of going against the times, flaunting your unconventional ideas and unorthodox ways, people will think that you only want attention and that you look down upon them. They will find a way to punish you for making them feel inferior. It is far safer to blend in and nurture the common touch. Share your originality only with tolerant friends and those who are sure to appreciate your uniqueness.

\section{Stir up Waters to Catch Fish}

Anger and emotion are strategically counterproductive. You must always stay calm and objective. But if you can make your enemies angry while staying calm yourself, you gain a decided advantage. Put your enemies off-balance: Find the chink in their vanity through which you can rattle them and you hold the strings.

\section{Despise the Free Lunch}

What is offered for free is dangerous - it usually involves either a trick or a hidden obligation. What has worth is worth paying for. By paying your own way you stay clear of gratitude, guilt, and deceit. It is also often wise to pay the full price - there are no cutting corners with excellence. Be lavish with your money and keep it circulating, for generosity is a sign and a magnet for power.

\section{Avoid Stepping into a Great Man's Shoes}

What happens first always appears better and more original than what comes after. If you succeed a great man or have a famous parent, you will have to accomplish double their achievements to outshine them. Do not get lost in their shadow, or stuck in a past not of your own making: Establish your own name and identity by changing course. Slay the overbearing father, disparage his legacy, and gain power by shining in your own way. scatter

Strike the Shepherd and the Sheep will

Trouble can often be traced to a single strong individual - the stirrer, the arrogant underling, the poisoned of goodwill. If you allow such people room to operate, others will succumb to their influence. Do not wait for the troubles they cause to multiply, do 
not try to negotiate with them - they are irredeemable. Neutralize their influence by isolating or banishing them. Strike at the source of the trouble and the sheep will scatter.

\section{Work on the Hearts and Minds of Others}

Coercion creates a reaction that will eventually work against you. You must seduce others into wanting to move in your direction. A person you have seduced becomes your loyal pawn. And the way to seduce others is to operate on their individual psychologies and weaknesses. Soften up the resistant by working on their emotions, playing on what they hold dear and what they fear. Ignore the hearts and minds of others and they will grow to hate you.

\section{Disarm and Infuriate with the Mirror Effect}

The mirror reflects reality, but it is also the perfect tool for deception: When you mirror your enemies, doing exactly as they do, they cannot figure out your strategy. The Mirror Effect mocks and humiliates them, making them overreact. By holding up a mirror to their psyches, you seduce them with the illusion that you share their values; by holding up a mirror to their actions, you teach them a lesson. Few can resist the power of Mirror Effect.

\section{Preach the Need for Change, but never reform too much at Once}

Everyone understands the need for change in the abstract, but on the day-to-day level people are creatures of habit. Too much innovation is traumatic, and will lead to revolt. If you are new to a position of power, or an outsider trying to build a power base, make a show of respecting the old way of doing things. If change is necessary, make it feel like a gentle improvement on the past.

\section{Never appear too perfect}

Appearing better than others is always dangerous, but most dangerous of all is to appear to have no faults or weaknesses. Envy creates silent enemies. It is smart to occasionally display defects, and admit to harmless vices, in order to deflect envy and appear more human and approachable. Only gods and the dead can seem perfect with impunity.

\section{Do not go Past the Mark you Aimed for; In Victory, Learn when to stop}

The moment of victory is often the moment of greatest peril. In the heat of victory, arrogance and overconfidence can push you past the goal you had aimed for, and by going too far, you make more enemies than you defeat. Do not allow success to go to your head. There is no substitute for strategy and careful planning. Set a goal, and when you reach it, stop.

\section{Assume Formlessness}

By taking a shape, by having a visible plan, you open yourself to attack. Instead of taking a form for your enemy to grasp, keep yourself adaptable and on the move. Accept the fact that nothing is certain and no law is fixed. The best way to protect yourself is to be as fluid and formless as water; never bet on stability or lasting order. Everything changes.

Greene uses anecdotes from historical figures such as Louis XIV, Talleyrand, Otto von Bismarck, Catherine the Great, Mao Zedong, Haile Selassie and various con artists in order to illustrate real-world application of the 48 rules. Greene's modern courtship theory was inspired by the writings of Baltasar Gracian and Niccolò Machiavelli. Greene also often uses an amoralapproach, mimicking Machiavellian language, leaving the reader to weigh the ethical implications of the laws (http://en.wikipedia.org/wiki/The_48_Laws_of_Pow er).

In the field of management, a writer in his book review states of Green's laws that: “Once this book is read together with all or any of the laws presented herewith would be an advantage to somebody who wants to practice and develop sense of leadership. It manifest insights that can help him to put on the complete suit of armor which can strongly protect him against machinations of the corporate people or the subordinates while take up the large shield of power with which he will be able to quench all the wicked ones burning missiles. Wise decisions are must and this book entails strategies that can be a supporting tool for somebody to gain credibility and absolute authority so that people would learn and practice submission. (Cont. in the next paragraph) The people under you would feel a sense of fear or respect so that they would rather avoid and solve conflicts that might arise among them. In this manner, this will be a great help to maintain peace inside and out of an organization. If good leadership has been performed, the organization as well will benefit. People are happy and of course productive and these are crucial factors to an organization to grow and prosper. (http://ezinearticles.com/?BookReview-on-the-48-Laws-of-Power-by-RobertGreene\&id=2053090).”

In the practice of political power in the Philippines, according to ProfessorRoland G. 
Simbulan in 2007, a good example at the national level is the Macapagal-Arroyo political dynasty that rules starting with Diosdado Macapagal, the late President in 1961 up to the present times.

As for the opposition, there are now two Cayetanos in the Senate and another in the House. The Senate seat used to be occupied by the senior "Companero" Cayetano; now Alan Peter (who was Congressman 1998-2007) has joined sister Pilar "Pia" Cayetano Sebastian who has been senator since 2004 up to 2010. Alan Peter's wife, Laarni has taken over his House seat, while a brother of Alan, Renren (councilor, 2004-2007) was elected vice mayor of Muntinlupa

(http://www.yonip.com/main/articles/MiscDoc0001.html).

Though Luis "Chavit" Singson(Congressman, 1987-92; Ilocos Sur governor 1998-2007) lost in his 2007 bid for a Senate seat, the Singson family dynasty is well entrenched in Ilocos Sur: ChavitSingson's son, Ronald is congressman, 1st district, Ilocos Sur; cousin Eric is congressman, 2nd district, Ilocos Sur; brother Jeremias is now vice governor ; niece Eva Marie Singson-Media was reelected mayor of Vigan together with Allen Singson, son of Eric, now mayor of Candon (http://www.yonip.com/main/articles/MiscDoc0001.html).

In the exercise of political power among Cebuanos, there are many names in Philippine politics who have gone so far in their administration setting up willed political dynasties (both in the local and national level) that sustained through times even if the 1987 Philippine Constitution, Article II, Section 26 prohibits it (Bernas, 2002). The following are the examples:

The Duranos: Tracing Power through Ace Durano. Joseph Hotchkiss Durano (born April 3, 1970), popularly known as Ace Durano, was one of the youngest to be elected representative to the 11th congress (1998-2001). He was an Assistant Majority Floor Leader and Vice Chairman of the Committee on Trade and Industry during this time. He was born to Elizabeth Hotchkiss-Durano and Ramon DuterteDurano III, son of Manong Amon the political warlord of the Philippines Ramon D. Durano III, Ace, as he is fondly called by his family and his constituents in the Fifth District of Cebu. While in law school, he was a research assistant of the Free Legal Assistance Group in Cebu City and at the Regional Trial Court Branch XXV in Davao City. In the 12th Congress (2001-2004), he was the Chairman of the Committee on Public Order and Security and Vice Chairman of the Committees on DPWH and on
Dangerous Drugs. He had served as the tourism secretary. On May 2, 2008, President Gloria Macapagal-Arroyo appointed Department of Tourism Secretary Joseph Ace Durano,acting general manager of the Philippine Tourism Authority (PTA), after Robert Dean Barbers' term expired (http://en.wikipedia.org/wiki/Joseph_Ace_Durano).

The Garcias: Tracing Power through Governor Gwendolyn Garcia. Gwendolyn Fiel Garcia (born October 12, 1955), commonly known as Gwen, is the Governor of the Philippine province of Cebu. She was first elected in 2004 and re-elected in 2007. She is Cebu's first woman governor. Garcia won by 7,000 votes in Philippine general election, 2004 and a historic half a million in Philippine general election, 2007. She is the eldest daughter of Congressman Pablo P. Garcia (the former governor of Cebu from 1995-2004) and Judge Esperanza "Inday" Fiel-Garcia, who had 8 children (4 sons). Lawyer-Congressman Pablo John Garcia (born in Cebu City on May 19, 1967) is the youngest. Her other brother Byron, is a security consultant for the Cebu provincial government, and caught global attention in 2007 due to Thriller (viral video). Her other brother, Winston Garcia, is the incumbent manager of the Government Service Insurance System (Philippines) (http://en.wikipedia.org/wiki/Gwendolyn_Garcia).

Currently, the lady governor still wins the gubernatorial race against Hilario "Jun-Jun Davide III, son of the former chief justice of the Republic of the Philippines in the concluded May 2010 elections.

The Gullases: Tracing Power through Congressman Eduardo Gullas. Eduardo R. Gullas (born October 13, 1930) is a Filipino politician. He has been elected to five terms as a Member of the House of Representatives of the Philippines, representing the First District of Cebu from 1992 to 2001, and from 2004 to the present. He is currently a member of KAMPI and the One Cebu party. Gullas had also served as the governor of Cebu during the administration of PresidentFerdinand Marcos (http://en.wikipedia.org/wiki/Eduardo_Gullas).

Currently, Digul, the 18-year-old grandson of Rep. Eduardo "Eddie" Gullas of Cebu's 1st district has just made history as the youngest councilor ever elected into office in the Philippines. He is the son of Gerald Anthony Gullas, only child of Representative Gullas... (http://cdn.ph/news_details.php?id=5977).

The Osmeñas: Tracing Power through Congressman Tomas Osmeña. Tomas "Tommy" de la Rama Osmeña (born July 26, 1948) was the former mayor and current Congressman in Cebu City. He was elected Mayor for the first time in 1988. He was re-elected Mayor in the 2004 Philippine elections. $\mathrm{He}$ is the son of the late SenatorSergio Osmeña Jr. and Lourdes dela Rama Osmeña, the grandson of former Philippine 
PresidentSergio Osmeña Sr. and the younger sibling of SenatorSergio Osmeña III. Married to Margarita "Margot" Lim Vargas (one of the current councilors in Cebu City), their union is blessed with their son Miguel

(http://en.wikipedia.org/wiki/Tomas_Osme\%C3\%B1 a).

The Ramas: Tracing Power through Mayor Michael Rama. Michael "Mike" Lopez Rama (born October 28, 1954) is a politician in the Philippines. Rama is the son of the late Fernando Rama and Natividada Lopez, the grandson of former Senator Vicente Rama. He has served three terms as ViceMayor of Cebu City and was elected the National President of the Vice Mayors League of the Philippines (VMLP).On May 12, 2010, he was proclaimed as the duly elected Mayor of Cebu City for the term $2010 \quad-\quad 2013$ (http://en.wikipedia.org/wiki/Mike_Rama).

Roland G. Simbulan in his lecture in 2007 stressed outsamples of past and present wellentrenched political dynasties in various parts of Mindanao are the following (by province):

Lanao del Sur - Alonto, Lucman, Adiong, Dimaporo, Macarambon, Dimakuta

Lanao del Norte - Badelles, Lluch, Cabili

Sultan Kudarat - Mangudadato

Cagayan de Oro City - Emano

General Santos City - Antonino

Zamboanga City -Lobregat, Lorenzo

Zamboanga del Norte - Adaza, Ubay, Carloto, Jalosjos

Zamboanga del Sur - Sagun-Lim, Enerio, Amatong, Cerilles

Tawi-Tawi - Jaafar

Camiguin- Romualdo

Misamis Occidental - Chiongbian, Ramiro

Misamis Oriental - Pelaez, Baculio

Saranggani- Chiongbian, Amatong

Sulu - Amilbangsa, Rasul, Abubakar, Ututalum, Tulawie

Surigao Norte - Navarro, Barbers, Ecleo

Surigao Sur - Falcon, Pimentel-Serra , Ty

Agusan del Sur - Paredes, Amante, Plaza

Bukidnon- Fortich, Zubiri, Acosta

Compostela Valley - Caballero

Cotabato -Pendatun, Mastura, Datumanong ,Matalam, Mangilen, Sinsuat

Davao City - Garcia, Lopez, Duterte

Davao del Norte - Del Rosario/Garcia, Sarmiento

Davao del Sur - Bautista, Cagas

Davao Oriental - Almario/Zosa, Palma Gil
The Caraga Region composed of the two Agusan provinces and Butuan City is said to be the "center" or "capital" of political dynasties in the Philippines which practically compete only among themselves for all congressional and local positions for the past 50 years or more. Studies made by academics and journalists for instance, identify no less than 10 members of the Plaza political clan holding and monopolizing political power from congressional seats, governorship, down to mayors, councilors and barangay chairs held by wife, sons, daughters, nephews, in laws, etc. (http://www.yonip.com/main/articles/MiscDoc0001.html) .

\section{B. RELATED STUDIES}

Coming to mind political dynasties to have ruled the Philippines, CENPEG in 2007 mentioned of "about 250 political dynasties (families) who have dominated Philippine politics at the national and local level and who have monopolized political power as families for the past 30 years and more. This is $0.00001667 \%$ of the country's 15 million families."

Professor Rolando G. Simbulan stated about political dynasties in the Philippines in his lecture in Western Mindanao State University and Universidad de Zamboanga last October 23-24, 2007 as he cited the abovementioned adding that in the Philippines, "each of the country's 80 provinces have political dynasties competing with each other for national and local elective positions. Dynasties have also expanded to monopolize many appointive positions (http://www.yonip.com/main/articles/MiscDoc0001.html)."

According to a recent study by the Philippine Center for Investigative Journalism, 2/3 of the members of the 8th to 12th Congress belong to political dynasties. We can just take a look at the Philippine Senate where we have combinations of brothers and sisters, mother and son, father and son out of only 24 members of the upper chamber (http://www.yonip.com/main/articles/MiscDoc0001.html).

Lapa, P. (2004) wrote about leadership that "managers are expected to play the roles of being "politicians", "diplomats" and "symbols" who make difficult decisions." This may mean that leaders in discharging their duties take into practice political power.

McClelland and David H. Burnham report that successful managers have need to influence others more for the benefit of people at the organization 
than self-aggrandizement. Managers who use their power with self-control will be more effective than those who wield power to satisfy a need to dominate others those who refuse to use their power out of a strong need to be liked (Stoner, Freeman and Girlbert, 1999).

Tampus, L. (2000) mentioned about the play of politics in leadership. He stressed that "the greater challenge is the myriad of the changes that confront us in the larger arena leadership and politics. Though there are a lot of training being conducted in every institution, there are still personal behaviors that dominated because of vested interests, lack of foresight and creativity. Some leadership behaviors are products of greed and grandstanding personality, which has imbibed the responsibilities because of nepotism, wealth, fortune and popularity."

Rama, F. (2002) in her research conclusion states that the "Organizational Culture and Work Values of the selected local government units are found to be interrelated. This is because the management principles adopted by the managers were actually intertwined with our Filipino Cultural Values, which when mixed and matched determined behavior and attitude of the work values of both government officials and employees."

Trani, A. (2007) concluded in his study emerging leadership styles of two local chief executives in Talisay City, Cebu. It turned out that Local Chief Executive A combined the autocratic and democratic styles while Local Chief Executive B was laissez-faire or free-rein. Both leadership styles are described by Kurt Lewin. The perception of the constituents indicated both of the chief executives' leadership styles.

Taking into account political power in women leadership, a recent study revealed that there is a reemergence of the empowerment of Filipino women through the political process, just as they were prior to the arrival of the ancient conquerors from Spain. Philippine women are rediscovering their strengths. Filipino women had been successful in implementing policies by becoming executive staff members, advisers to politicians, and as advocates within nongovernmental organizations (http://en.wikipedia.org/wiki/Women_in_the_Philipp ines).
Lubguban, M.G. (2010) mentioned, "Women leadership in the national capital region is not a rare case in the Philippines. Although in the past, women in Siquijor were confined in the home, they however took important roles like taking care of the children and assisting their husbands who worked for the family's income."

Lubguban, M.G. also mentioned that "these concepts of women as leaders do not hold true only in the corporate world but in political life as well. In a study conducted in 1990 on women councilors, the findings showed that most of the women councilors are married and two in five women have more than five children, the mean number of children ever born being 4.3. The study further elaborated that politics is a demanding profession especially for married women for their political life would keep them away from home for an extended period. However, their participation may be facilitated if their children are older and do not need much parental attention (Domingo, 1995).

Laplap, C. F. as cited by the Philippine Association for Graduate Education Journal indicates that "the number of female top managers has increased because more women have ventured into fields and occupations formerly dominated by men. (Cont. in the next paragraphs) The number of women who hold the most senior positions of leadership serving has risen since 1970. However, women managers are scarce as supported by Burke (2005) who mentioned that women merely comprise less than $0.005 \%$ of the world's political, business and industrial leaders.

\section{CONCLUSION}

The exposition of excerpt theories showed diverse power stratagem on rational choice upon use. The speculation upon application depends upon perception through discernment on processing based on mindset and application to the scenario upon which it is anchored upon theories towards political reality. Thus, leaders are entangled ways and means on how they are to achieve their end(s) through the use of power and among those who aspire towards the end of leadership per se. 


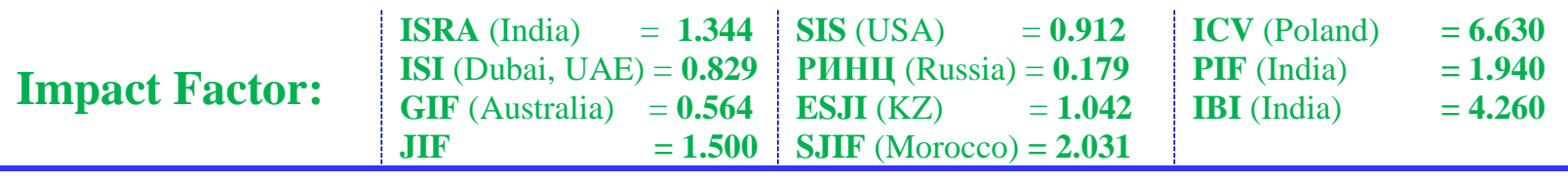

\section{References:}

1. Bernas, Joaquin G. (2002) The 1987 Philippine Constitution A Reviewer-Primer. Quezon City: Rex Printing Company, Inc.

2. Dannug and Campanilla (2004) Politics, Governance and Government with Philippine Constitution. Quezon City: C \& E Publishing, Inc.

3. De Leon, Hector S. (1999) Textbook on Philippine Constitution. Manila: Rex Bookstore.

4. Ebenstein, William and Alan (2000) Great Political Thinkers. Singapore: Thomson Learning Asia.

5. Hatch, Mary Jo. (1997) Organization Theory Modern, Symbolic and Postmodern Perspectives. U.S.A: Oxford University Press.

6. Martires CR, Fule GS (2000) Management of Human Behavior in Organizations. Mandaluyong City: Echanis Press.

7. Cabonce Rodolfo SJ (1983) An EnglishCebuano Visayan Dictionary. Philippines: National Book Store.

8. Moten AR, Islam SS (2007) Introduction to Political Science. Singapore: Thomson Learning Asia.

9. Palispis Epitacio S (1996) Introduction to Sociology and Anthropology. Quezon City: Rex Printing Company, Inc.

10. Stoner James AF, Freeman RE, Gilbert DR (1999) Jr. Management: (Sixth Edition). 1999. Singapore: Prentice Hall Inc.

11. Suarez Rolando (2005) The 1987 Constitution of the Republic of the Philippines Made Easy. Quezon City: Rex Printing Company, Inc.

12. Zulueta, Francisco M (2003) Foundations and Dynamics of Political Science. 2003. Quezon City: Academic Publishing Corporation

13. Domingo Lita J, et. al. (2010) as cited by Lubguban M.G. (Jan.-Dec., 1995). Women's in Political Affairs, Philippine Social Science Review. Vol. 52. PAGE Journal Region VII. 2010 Issue.

14. Lapa Porponio B (2004) Management Practices and Leadership Effectiveness of Barangay Chairmen in Cebu City. Unpublished Doctoral Dissertation, Cebu Normal University, Cebu Normal University.

15. Lapiz, Gary B (2009) Rawls' Theory of Justice: A Philippine Political Socio-Economic Perspective. 2009. Unpublished Master's Thesis, Cebu Normal University.

16. Lubguban, Mary Grace B. (2010) Government Women Executives in Siquijor: Case Study.
2010. Unpublished Master's Thesis, Cebu Normal University, Cebu City.

17. Rama Florecita $\mathrm{T}$ (2002) Organizational Culture and Work Values of the Selected Local Government Units in Cebu Province: An Organizational Development Program. 2002. Unpubished Doctoral Dissertation, Cebu Normal University, Cebu City.

18. Tampus, Lolito G (2000) Health Pratices, Leadership Behaviors, Personality and Performance of Managers. 2000. Unpublished Doctoral Dissertation, Cebu Normal University, Cebu City.

19. Trani, Alan A (2007) Governance of Local Chief Executives of Talisay City, Cebu: Emerging Leadership Style. 2007. Unpublished Doctoral Dissertation, Cebu Normal University, Cebu City.

20. (2010) Available: http://en.wikipedia.org/wiki/Ferdinand_Marcos (Accessed: July 2, 2010)

21. (2010) Available: http://en.wikipedia.org/wiki/Gloria_MacapagalArroyo (Accessed: July 2, 2010)

22. (2010) http://www.chanrobles.com/article2.htm (Accessed: July 2, 2010)

23. (2010) Available: http://en.wikipedia.org/wiki/Power \%28philoso phy\%29 (Accessed: July 2, 2010)

24. (2010) Available: http://www.earthlingcommunication.com/blog/r eview-of-the-48-laws-of-power-by-robertgreene.php (Accessed: July 2, 2010)

25. (2010) Available: http://ezinearticles.com/?Book-Review-on-the48-Laws-of-Power-by-RobertGreene\&id=2053090 (Accessed: July 2, 2010)

26. (2010) Available: http://en.wikipedia.org/wiki/People_Power_Rev olution (Accessed: July 11, 2010)

27. (2010) Available: http://en.wikipedia.org/wiki/Pablo_P._Garcia (Accessed: July 11, 2010)

28. (2010) Available: http://en.wikipedia.org/wiki/Gwendolyn_Garcia (Accessed: July 11, 2010)

29. (2010)

Available: http://en.wikipedia.org/wiki/Tomas_Osme\%C3 \%B1a (Accessed: July 11, 2010)

30. (2010)

Available: http://www.lawphil.net/statutes/repacts/ra1989/r a_6713_1989.html (Accessed: July 11, 2010) 


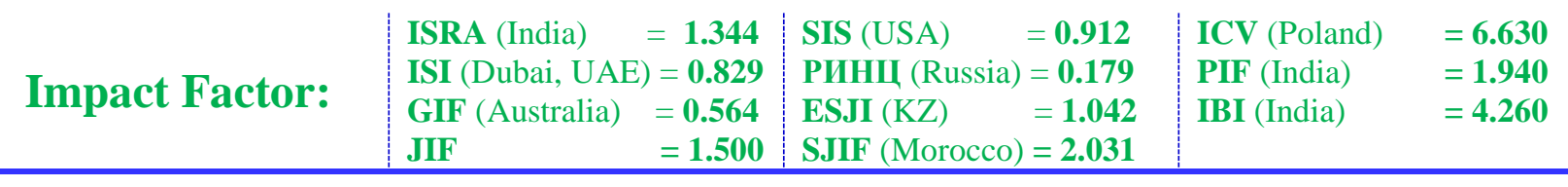

31. (2010)

Available: http://en.wikipedia.org/wiki/Joseph_Ace_Duran o (Accessed: July 11, 2010)

32. $(2010)$

Available: http://en.wikipedia.org/wiki/Eduardo_Gullas (Accessed: July 11, 2010)

33. (2010) Available: http://cdn.ph/news_details.php?id=5977 (Accessed: July 11, 2010)

34. (2010) Available: http://en.wikipedia.org/wiki/Mike_Rama (Accessed: July 11, 2010)

35. (2010) http://www.yonip.com/main/articles/MiscDoc0001.html (Accessed: July 11, 2010)
36. (2010) Available: http://cenpeg.org (Accessed: July 11, 2010)

37. (2010) Available: http://en.wikipedia.org/wiki/Women_in the Ph ilippines (Accessed: July 12, 2010)

38. (2010) Available: http://twitter.com/erickkristian/status/17910057 428 (Accessed:August 1, 2010)

39. (2010) Available: http://translation.babylon.com/english/tovisayan/\# (Accessed: August 3, 2010) 